\title{
転動流動層装置によるコーティング用核粒子の調製
}

\author{
坂 本

\section{The Preparation of Core Particles for Coating by Rotating Fluid Bed Equipment} \\ by \\ Hiroshi SAKAMOTO ${ }^{\dagger}$

\begin{abstract}
A granulator was developed which could produces granules with a smooth surface and narrow particle size distribution in order to improve coating efficiency. This study reports on the granulation process using the new granulator.

For evaluation of granules obtained by altering process parameters as cores for coating, the shape, apparent specific gravity, particle size and fractal dimension were examined.

The following condition were found to be essential to obtain granules suitable for subsequent coating process :

1) The size of spray mist should be kept in the range of $40 \mu \mathrm{m}$

2) The moisture content of the fluid bed should be made as high as possible provided that good fluidization can be maintained.
\end{abstract}

浩*

Key Words : Rotating Fluid-bed Equipment, Coating Granulation, Surface Morphology, Fractal

\section{1. 緒言}

流動首装置により造粒される顆粒剂・散剂(細粒) は，軽質で表面形状も不規則なものが多く，コーティ ング用核粒子に適しているとは言えない。さらにコー テイング操作において粉化や団粒の生成等の問題が生 じることもある。これらの問題を解決するために，筆 者らは転動流動首装置を開発した。

流動造粒では, 造粒機内で流動化した原料粉体にバ インダー溶液をスプレーすることにより，粒子間に付 着・凝集が生じて造粒が促進される ${ }^{1)}$ 。したがって， スプレーミスト径が造粒物の表面形状等の製品特性に 大きな影響を及ぼすと考えられる。しかしミスト径と

1994年 3月 8日受付

第 31 回粉体に関する討論会(1993 年 10 月, 神戸)にて発表

*(株) パウレック粉体工学研究所( T563 大阪府池田市豊島南 2-15)

$\dagger$ POWREX Corp.

(2-15 Toyoshima-minami, IKeda-shi Osaka 563)
造粒物の物性に関する研究は，いまだ不充分である。 本研究では，コーティング用核粒子を加工する目的 で，新開発した転動流動首装置を用いてスプレーミス 卜や層内水分, ならびにバインダ一湌度を種々変化さ せて造粒を行った。得られた造粒物については, 粒度 分布やフラクタル次元による形状，あるいはみかけ密 度を測定するとともにこれらの物性值とスプレーミ スト径および操作条件の関係を調べた。その結果，コ 一ティング用核粒子を加工できる操作条件を明らかに することができたので報告する。

\section{2. 実験方法}

\section{1 実験装是}

開発した転動流動層装置の概略をFig. 1に示す。こ の装置は形式的には複合型であり，搅拌と流動首の特 長を持つ。さらに新型の噴第ノズルが取付られている。 装置設計においては，原料粉末に対してどのような力 を加えると目的とする造粒物が生産できるかを検討し 


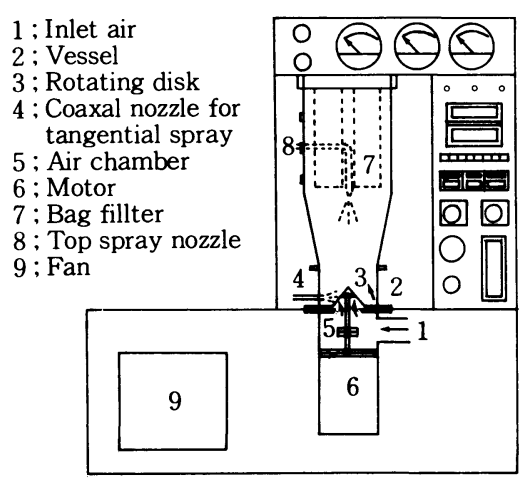

Fig. 1 Rotating fluid bed equipment(Model MP-01)

た。コーティング用核粒子としては球形で重質なもの が望まれる。したがって, 造粒操作中は对象物に対し て剪断力と転動圧密を作用させる必要がある。そこで 凸状体を放射状に付けた回転体（回転デイスク）を流動 層装置の底部に設けた。流動化空気は, 容器底部中央 から通気して, 回転ディスクと容器底面の間䏚を通 り, 回転デイスク外周端部を経て对象物を流動させ る。造粒容器断面積相当の風速を, 通常の流動層装置 と同等の $0.5 \sim 2.0 \mathrm{~m} / \mathrm{s}$ とた。

流動状態の粉末は，スプレーにより湿潤され，凝集 と分散を繰り返しながら，回転ディスクの転動圧密作 用を受けるようにした。さらに，通常の流動層装置で 流動化が困難な粉末(微粉末で凝集性の強い粉末等) も，回転ディスクの敩拌・分散作用により吹き抜け （流動不良）を解消させて, 容易に安定した流動層が形 成できるように工夫した。

適切なスプレーには，1）ミストの良好な分散状態，

2) 適当なミスト径，3）ノズル先端近傍に粒子が無いこ と，4）ノズル先端〜粒子間の距離が短いことが重要で あると考えられる。従来のノズルを流動層の下部に挿 入した場合, 結合剂溶液が霧状に分散する以前に原料 粉末と接触・付着することから，局部的な濡れ過利あ るいはノズル先端に粉末が付着などしてスプレーは阻 害されることが多い。これらの問題解決と1)〜4)を実 現するためにFig. 2 に示す新型ノズルを開発し た。すなわちノズル外周に鞘を設け，鞘とノズルの間

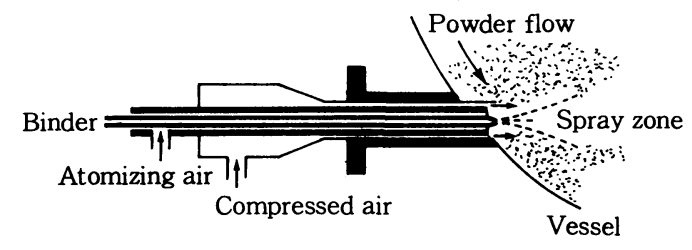

Fig. 2 Coaxal nozzle for tangential spray
から圧縮空気を吹き出し，ノズル先端部でスプレーミ ストが十分に第化する距離・空間(スプレーゾーン)を 形成させるように工夫した。このスプレーゾーンにお いてスプレーミストと粉体粒子を接触・付着させて造 粒を促進させる。

本研究では, ノズル位置と造粒性の関係を明らかに する目的で, 造粒容器の下部側面に付設した新型ノズ ル(接線スプレーと呼ぶ) と, 従来のノズルを上部から 下向きにスプレーするトップスプレ一方式を比較した。

\section{2 造粒用試料}

造粒用粉体試料には, 乳糖(DMV-200M), 局方コ ーンスターチ(松谷化学工業(株)製), アセトアミノフ エン(粉砕品, 吉富製薬(株)製)を用いた。また結合剤 にはヒドロキシプロピルセルロース(信越化学工業 （株）製 HPC-LEP）を3,4,5,6,7\%の浪度に調製して採 用した。ここで結合剤の溶媒は精製水である。Table 1 に固形分処方を示す。

\section{3 スプレーミスト径の測定}

ミスト径の測定はレーザー式粒度分布測定器 $(\mathrm{Ma}-$ lvern Instrument: Model 2600C)を用いて, Fig. 3 に示すような方法により，噴霧空気量および夜速度を 変化させて行なった。ノズルには小容量型(970型, 口 径 $\left.1.2 \times 10^{-3} \mathrm{~m}\right)$ と大容量型 $\left(940\right.$ 型, 口径 $\left.2.2 \times 10^{-3} \mathrm{~m}\right)$ を採用した。また結合剂溶液としては5,8\%の溇度に 調製したものを用いた。さらに測定距離はノズル先端

Table 1 Test formulations in granulation

\begin{tabular}{lcc}
\hline & MP-01 & MP-01 \\
\hline Lactose & $0.42 \mathrm{~kg}$ & $\ldots \ldots$ \\
Corn starch & $0.18 \mathrm{~kg}$ & $\ldots \ldots$ \\
Acetaminophen & $\ldots \ldots$ & $0.6 \mathrm{~kg}$ \\
Total & $0.6 \mathrm{~kg}$ & $0.6 \mathrm{~kg}$ \\
\hline Binder. HPC-LEP & $0.024 \mathrm{~kg}$ & $0.024 \mathrm{~kg}$ \\
\hline
\end{tabular}

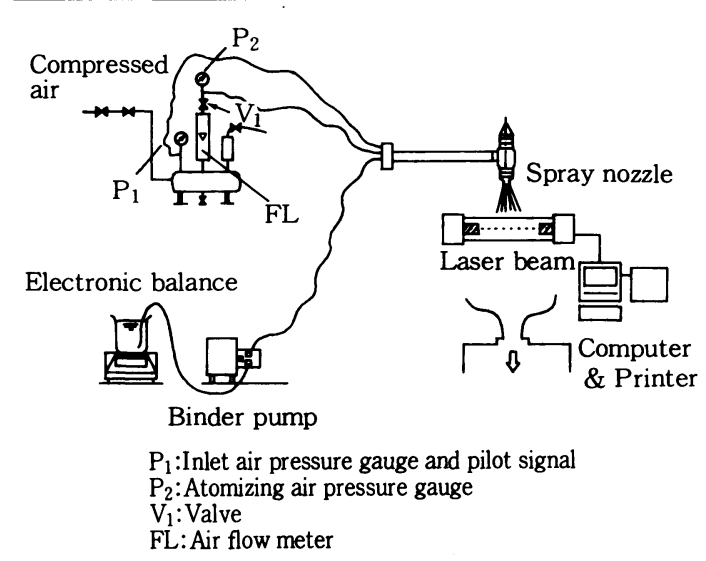

Fig. 3 System measuring droplet size distribution 
から $0.045,0.09,0.18 \mathrm{~m}$ と変化させた。なおミスト径 の測定は室温で行なっている。

\section{4 造粒物の物性測定方法}

ロータップふるいを用いて求めた質量基準に基づく 粒度分布から，平均粒子径 $\left(D_{\mathrm{g}, 50}\right)$ および幾何標準偏差 $\left(\sigma_{\mathrm{g}}\right)$ を求めた。また, みかけ密度はJIS-9721に基づき 測定している。さらにフラクタル次元は, 太田 ${ }^{2}$ らの方 法を用いて測定した50個の平均値により表現した。

\section{5 造粒操作条件}

造粒実験には転動流動首装置(マルチプレックス $\mathrm{MP}-01$ 型）を用いた。流動化風量 $=30 \mathrm{~m}^{3} / \mathrm{h}$, 給気温 度 $=348 \mathrm{~K}$, 回転デイスクの回転数については, 綿野 ${ }^{3)}$ らの報告を参考にして380rpmで操作した。外気につ いては特に制御を行なわずに実験を行なった。スプレ 一速度は造粒中の湿潤粉体の含水率(湿量基準：以後 層内水分と呼ぶ)がスプレ一開始後 20 分で $12.5,15.0$, 17.5，20.0，22.5\%になるように初期添加スプレ一速 度を変化させた。さらに20分以後はこの層内水分を保 持できるスプレ一速度で添加した。また噴蓩空気量 についても $0.028,0.035,0.037,0.042,0.051,0.065$, $0.076 \mathrm{~m}^{3} / \mathrm{min}$ と変化させて造粒実験を行なった。こ の場合，小容量ノズル(970型)を使用している。

\section{3. 実験結果と考察}

\section{1 喷雾空気旦とミスト径および造粒物}

ノズル先端から $0.045 \mathrm{~m}$ の距離で測定したミスト径 と噴務空気量の関係をFig. 4に示す。ここでミスト径 は質量基準ふるい下分布の $90 \%$ 径 $\left(D_{\mathrm{m}, 90}\right)$ 相当で表現 した。Fig. 4から，ミスト径 $\left(D_{\mathrm{m}, 90}\right)$ は噴霧空気量が增 加すれば小さくなっていることが分かる。しかし小容 量ノズル(970 型) は $0.1 \mathrm{~m}^{3} / \mathrm{min}$ ，大容量ノズル $(940$

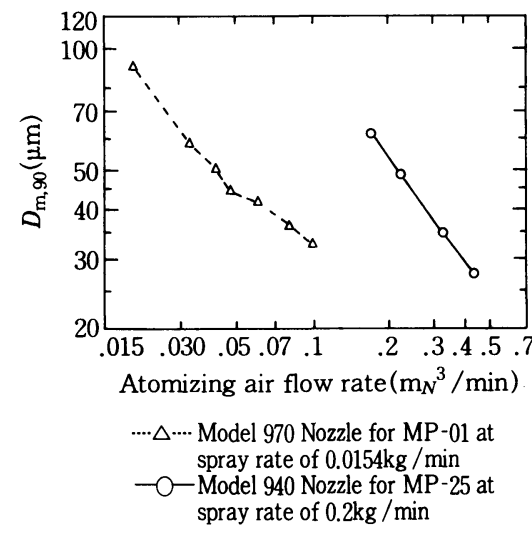

Fig. 4 Relation between atomizing air flow rate and droplet size

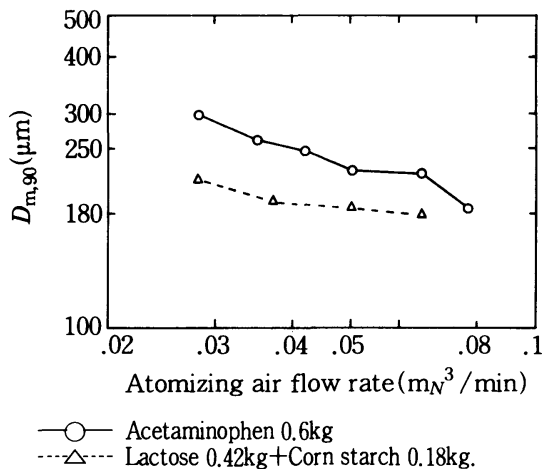

Spray rate $0.306 \mathrm{~kg} / 1200 \mathrm{sec}+0.037 \mathrm{~kg} / 247 \mathrm{sec}$.

Binder concentration 7.0\% HPC-LEP in water solution. Model 970 Nozzle(Top spray)

Fig. 5 Relation between atomizing air flow rate and granule size

型)では $0.6 \mathrm{~m}^{3} / \mathrm{min}$ に噴第空気量の限界があった。こ れは噴茅空気流路の圧力損失によるものと考えられた。

Fig. 5は噴䋷空気量を変化させて造粒操作を行な い，得られた造粒物の平均粒子径 $\left(D_{\mathrm{g}, 50}\right)$ を示したもの である。 $D_{\mathrm{g}, 50}$ は噴第空気量を增加させると小さくなっ ていることが分かる。噴茅空気量が多くなるとミスト 径が小さくなるので(Fig. 4), 造粒に寄与する結合剤 量が少なくなることから，平均粒子径が小さくなった と考えられる。また，アセトアミノフェン系(○)は， 乳糖・コーンスターチ系 $(\Delta)$ に比べて造粒物の平均粒 子径が大きいことが分かる(Fig. 5)。これは, 原料粉 末の溶解性・吸水性等により造粒に必要な首内水分が 異なることによるものと考えられる。すなわち，ア七 トアミノフェンはやや難溶性で, 吸水性もコーンス夕 一チに比較して小さいので, 結合剤が粒子内部に浸透 する割合が少なく，粒子表面において造粒に関与する 結合珮量が多くなったためと考察される。

粒子形状を表わすフラクタル次元と噴蓩空気量の関 係をFig. 6に示す。ここでフラクタル次元が小さいほ ど造粒物の表面形状は円滑であることを示している。 Fig. 6から，アセトアミノフェン系および乳糖・コー ンスターチ系とも噴霧空気量が多いほどフラクタル次 元が小さい值を示していることが分かる。このことは ミスト径が小さくなれば小さな凝集物が生成し, さら にこの凝集物が凝集して成長することから表面形状が 円滑になったと考えられる。表面形状の平滑な造粒物 が得られているのは, 噴葇空気量が $0.07 \mathrm{~m}^{3} / \mathrm{min}$ 付近 である。この噴第空気量におけるミスト径は約 $40 \mu \mathrm{m}$ である(Fig. 4)。 


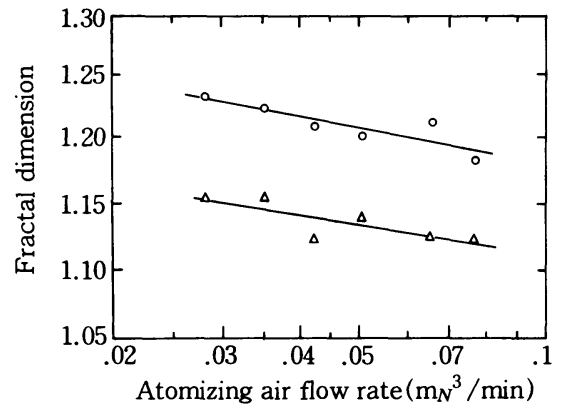

- Acetaminophen $0.6 \mathrm{~kg}$

$-\triangle$ Lactose $0.42 \mathrm{~kg}+$ Corn starch $0.18 \mathrm{~kg}$.

Spray rate $0.306 \mathrm{~kg} / 1200 \mathrm{sec}+0.037 \mathrm{~kg} / 247 \mathrm{sec}$

Binder concentration 7.0\% HPC-LEP in water solution.

Model 970 Nozzle(Top spray)

Fig. 6 Relation between atomizing air flow rate and fractal dimension

\section{2 首内水分と造粒物}

次に, 流動層内部の原料粉末の層内水分が20分で $12.5 ， 15.0 ， 17.5 ， 20.0 ， 22.5 \%$ になるように，流動化 空気の蒸発能力を考慮したスプレ一速度で造粒した結 果をFig. 7に示す。 $D_{8,50}$ の大きい造粒物は，流動層内 の水分が多い場合に生成させていることが分かる。こ れは, 首内水分が高いと付着・凝集に関与する結合剤 溶液が多くなり，その結果，造粒物の粒子径が大きく なったと考えられる。アセトアミノフェン系の場合, $20 \%$ 以上の層内水分では過剩湿潤のため流動不良とな り，粗大粒子が生成したので運転を停止した。乳糖・ コーンスターチ系でも層内水分が $25 \%$ 以上で，アセ卜 アミノフェン系と同様に過剩湿潤となり流動不良が生 じ，さらに装置内壁への付着も多くなったため造粒実 験を中止した。これらの結果より，造粒には原料粉末

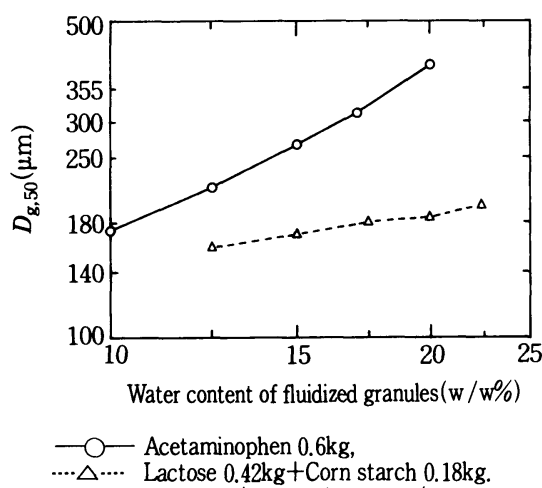

Spray rate $0.306 \mathrm{~kg} / 1200 \mathrm{sec}+0.037 \mathrm{~kg} / 247 \mathrm{sec}$.

Binder concentration 7.0\% HPC-LEP in water solution.

Model 970 Nozzle(Top spray)

Fig. 7 Relation between water content and granule size

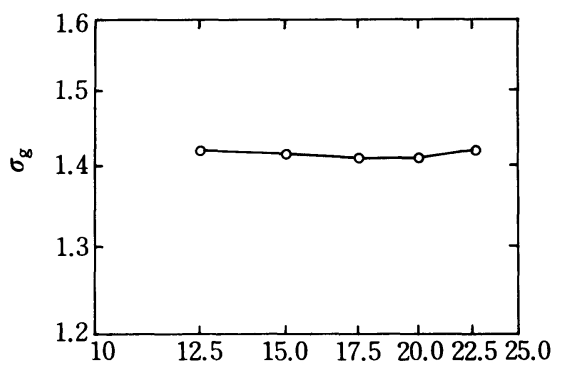

Water content of fluidized granules ( $\mathrm{w} / \mathrm{w} \%)$

Lactose $0.42 \mathrm{~kg}+$ Corn starch $0.18 \mathrm{~kg}$,

Spray rate $0.306 \mathrm{~kg} / 1200 \mathrm{sec}+0.037 \mathrm{~kg} / 247 \mathrm{sec}$.

Binder concentration 7.0\% HPC-LEP in water solution. Model 970 Nozzle.

Fig. 8 Relation between water content and $\sigma_{\mathbf{g}}$

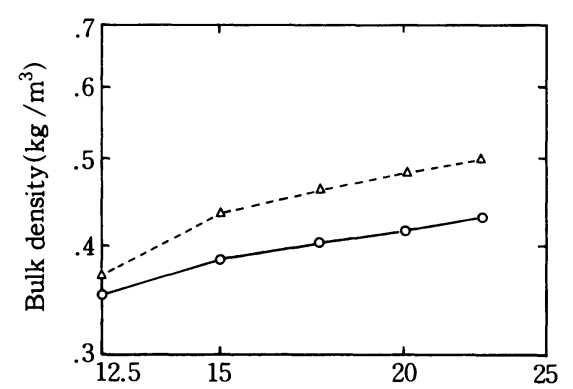

Water content of fluidized granules (w /w\%)

$\cdots \Delta \cdots$ Tangential spray,

.... $\bigcirc \cdots .$. Top spray.

Lactose $0.42 \mathrm{~kg}+$ Corn starch $0.18 \mathrm{~kg}$,

Spray rate $0.306 \mathrm{~kg} / 1200 \mathrm{sec}+0.037 \mathrm{~kg} / 247 \mathrm{sec}$

Binder concentration 7.0\%HPC-LEP in water solution.

Model 970 Nozzle.

Fig. 9 Reletion between water content and bulk density

の物性(例えば吸水性)に応じた適当な範囲の層内水分 が存在することが確認できた。過㮃湿潤を生じない範 囲内で層内水分を高くした場合, 幾何標準偏差 $\left(\sigma_{\mathrm{g}}\right)$ に 大差は見られない(Fig. 8)が, みかけ密度は大きくな つていることが分かる(Fig. 9)。この結果, コーティ ングに適したみかけ密度の高い(重質)造粒物は, 流動 不良が発生しない範囲内で層内水分を高くすることに より加工できることが確認できた。

\section{3 スプレー方式と造粒物のみかけ密度}

接線スプレ一方式と, 上部から下向きにスプレ一す るトップスプレ一方式とを比較した結果をFig. 10に 示す。接線スプレ一方式を採用して生成した造粒物の みかけ密度は, 結合剂溶液浱度の増加にともない大き くなっていることがわかる。一方,トップスプレ一方 式により生成した造粒物のみかけ密度は, 極大值をと った後小さくなる傾向を示した。接線スプレ一方式で 


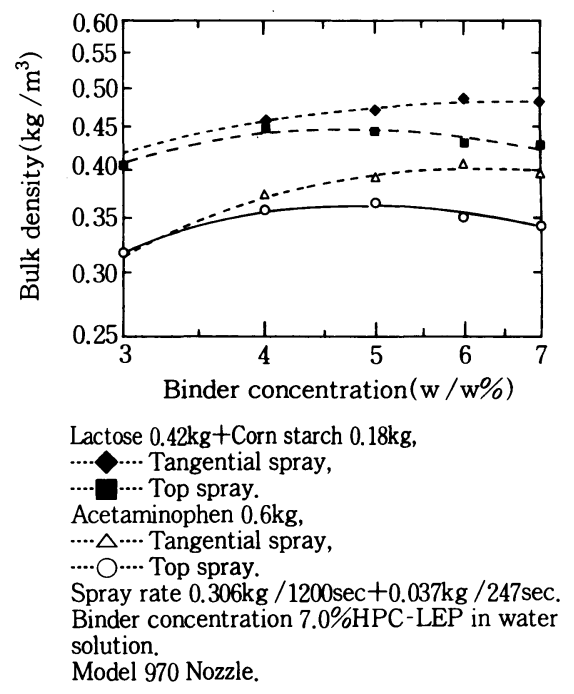

Fig. 10 Effects of binder concentration and spray mode on bulk density of granules

は，粉体試料にミストが接触・付着する距離が短いの で，スプレーされた直後の粘度状態で，ミストが原料 粉末と接触・付着して浸透することから，粒子間距離 が小さくなる。その結果，みかけ密度が大きい(重質 な)造粒物が生成されたと解釈される。これに比べて, トップスプレー方式では，スプレーされたミストが原 料粉体と接触する前に幾分か乾燥される。そのため に，結合剤溶液がさらに高㴗度な状態になり，高結合 力と, 低い溶液浸透速度状態となるので, 粒子間距離 は大きくなる。このような理由により，トップスプレ 一方式では, みかけ密度の小さな(軽質)造粒物が生成 されたと推察される。以上の結果より，下部接線スプ
レー方式は，トップスプレー方式に比ベて，重質造粒 に適していることが分かった。

\section{4. 緒 言}

コーティングに適した核粒子を加工するため，転動 流動層装置を開発した。さらに，新しい噴霧ノズルを 作成し，ミスト径を測定するとともに，造粒条件を変 化させて実験を行い，得られた造粒物の物性を調べ た。その結果以下のことが言える。

コーティングに適した核粒子を加工するためには, 1) 表面形状が滑らかで(フラクタル次元が小),2) み かけ密度は大きく(重質)，3）平均粒子径も要求規格範 囲内で可能な限り大きく，4）粒度分布をシャープ(幾 何標準偏差 $\sigma_{\mathrm{g}}$ が小)にしなければならない。

これらの1）4）を実現する操作は，A）スプレーミ スト径が約 $40 \mu \mathrm{m} に$ なるよう噴第空気量にする。B） 層内水分は流動不良が生じない範囲で高くする(アセ トアミノフェン系で10～17.5\%，乳糖・コーンスター チ系で12.5 22.5\%)。C) バインダーは原料粉末の物 性(例えば吸水性・溶解性等)および結合力と浸透速度 を配虑して，できるだけ高い湌度 $(5 \sim 7 \%)$ にする。 D) スプレーノズルの位置は流動層の下部に付設すれ ばよいことが分かった。

この様な操作条件において，コーティングに適した 核粒子が得られることが確認できた。

[謝 辞] スプレーミストの測定にご協力して頂い た, 信越化学工業(株)合成技術研究所, 丸山氏はじめ 関係の方々に深く感謝致します。

\section{Nomenclature}

$D_{\mathrm{m}, 90}:$ particle diameter of $90 \%$ cumulative undersize
$D_{\mathrm{g}, 50}: 50 \%$ mean particle diameter

$(\mu \mathrm{m}) \quad \sigma_{\mathrm{g}} \quad$ : geometric standard deviation $(\mu \mathrm{m})$

\section{References}

1) Nishimura. K., H. Kakizaki, T. Fukazawa, S. Kishitani, K. Kasahara and T. Asai : Yakuzaigaku, 38, 196(1978)

2) Oota. M., Y. Mizuno, K. Terashita and K. Miyanami : Abstr. of the 9th Symp. on Particulate Preparations and Designs, p.5, Mie,
Japan(1992)

3) Watano. S., K. Terashita and K. Miyanami : Abstr. of the 7th Symp. on Particulate Preparations and Designs, p.55, Shiga, Japan (1990) 